\title{
Effect of Planting Density and Fertilizers on Growth and Development of Tissue Culture Banana $c v$. Ney Poovan (AB) under Hill Zone of Karnataka
}

\author{
H. S. Yallesh Kumar*, Kulapati Hippargi, B. S. Shivakumar, I. B. Biradar, \\ M. P. Basavarajappa and Mallikarjuna G. Awati \\ Department of Fruit Science, College of Horticulture, Bagalkot, University of Horticultural \\ Sciences, Bagalkot (KNK), India \\ *Corresponding author
}

\begin{tabular}{l} 
K e y w o r d s \\
$\begin{array}{l}\text { Spacing, Plant } \\
\text { density, Fertilizers, } \\
\text { Ney pooovan, } \\
\text { Suckkers, AGR }\end{array}$ \\
\hline Article Info \\
$\begin{array}{l}\text { Accepted: } \\
\text { 28 July } 2020 \\
\text { Available Online: } \\
\text { 10 August } 2020\end{array}$ \\
\hline
\end{tabular}

\section{Keywords}

Spacing, Plant density, Fertilizers,

Ney pooovan, Suckkers, AGR

\section{Accepted:} Available Online: 10 August 2020

\section{A B S T R A C T}

The field experiment was conducted at College of Horticulture, Mudigere, to study on influence of planting density and fertilizers on growth and development of tissue culture banana $c v$. Ney poovan (AB) under hill zone of Karnataka during 2017-2018 with Factorial Randomized Block Design. The treatments were replicated twice with three factors and three levels. First spacing $S_{1}-2.0 \times 2.0 \mathrm{~m}, \mathrm{~S}_{2^{-}}-3.0 \times 2.0 \mathrm{~m}$ and $\mathrm{S}_{3}-2.0 \times 4.0 \mathrm{~m}$, second plant density $\mathrm{D}_{1^{-}}$single plant per pit, $\mathrm{D}_{2}$ - double and $\mathrm{D}_{3}$-triple plants per pit and third factor fertilizers $\mathrm{F}_{1}-100 \% \mathrm{RDF}, \mathrm{F}_{2}-125 \% \mathrm{RDF}$ and $\mathrm{F}_{3}-150 \% \mathrm{RDF}$. The results revealed that, as influenced by different levels of spacing, plant density and fertilizers on plant and ratoon crop of banana. The maximum pseudostem height of plant and ratoon crop was recorded in $S_{1}(310.26$ and $304.47 \mathrm{~cm})$ at shooting stage and plant density in $\mathrm{D}_{3}$ $(310.44$ and $309 \mathrm{~cm})$. The pseudostem girth and number of leaves was recorded maximum in $\mathrm{S}_{3}$ at $5^{\text {th }}$ MAP $(30.78$ and $27.41 \mathrm{~cm}),(11.52$ and 10.49$)$ and in plant density was $\mathrm{D}_{1}$ at $5^{\text {th }}$ MAP (31.85 and $28.24 \mathrm{~cm})(11.88$ and 11.04$)$ and shooting stage $(62.61$ and $60.18 \mathrm{~cm})$ and 18.39 and 17.32) of plant and ratoon crop. Whereas in fertilizer $\left(\mathrm{F}_{3}\right)$ was recorded maximum number of leaves at $5^{\text {th }}$ MAP (11.54 and 10.57). The absolute growth rate for pseudostem height was maximum in $\mathrm{D}_{2}$ during $3^{\text {rd }}$ to $5^{\text {th }}$ MAP $(1.04 \mathrm{~cm}$ day-1). The maximum number of suckers production per pit of plant and ratoon crop was obtained in $\mathrm{S}_{3}$ at $7^{\text {th }}$ MAP (6.52 and 7.24) and shooting (9.04 and 8.32). with respect to plant density highest suckers production was registered in $\mathrm{D}_{1}$ at shooting (8.33). Whereas in fertilizer levels, the maximum number of suckers (6.75 and 8.04) was found in $F_{3}$. While interactions the treatment $S_{3} D_{1}$ recorded the maximum suckers per pit at shooting (10.07 and 8.88) in plant and ratoon crop.

\section{Introduction}

Banana (Musa spp) is one of the most important herbaceous fruit crops in world, belongs to the family Musaceae. By virtue of its multiple uses banana is popularly known as "Kalpataru". It is an important crop of sustenance and farmers can ensure year-round production and income. Banana accounts 33.4 $\%$ total fruit production in India with an area of 0.89 million hectare with a total production of 33.89 million MT and productivity of 
37.10 metric tonnes per hectare (Anon., 2018).

The cultivar 'Ney Poovan' also known as Elakkibale (Puttabale) is a backyard cultivar of choice, now assumes commercial cultivation. Now a day's tissue culture banana $c v$. Ney Poovan is acquiring lot of importance in hill zone of Karnataka Higher production is a prime objective hence, by adopting good yielding varieties, selection of tissue cultre plants, choosing the right plant density, right inter cultural practices, water and fertilizer management are important to gain commercial yield per unit area.

Modified planting system to increase the plant density by planting one or more plants per pit at wider space is a recent and novel concept. It provides economic use of land, efficient utilization of solar energy, water, fertilizer, pesticides and ultimately leads to increased growth and productivity. Water and nutrients are the key important factors in banana production and research study has clearly demonstrated that for higher productivity of banana, application of recommended doses of essential nutrients at appropriate crop growth stage is necessary. Nutritional requirement has not been optimized in tissue culture banana especially $c v$. Ney Poovan (AB) for adopting the high density planting system with two or more plants per pit and effectively utilization of land and solar energy. This clearly emphasizes the need for research on these aspects which is expected to provide vital information to the growers.

\section{Materials and Methods}

The study was carried out in fruit science experimental field, College of Horticulture, Mudigere, Karnataka during 2017 and 2018 of both plant and ratoon crop. The experiment was laid out in a Factorial Randomized Block Design. The treatments were replicated twice with three factors consisted of spacing, plant density and different levels of fertilizers. The first factor consists of three spacings viz., $\mathrm{S}_{1^{-}}$ $2.0 \times 2.0 \mathrm{~m}, \mathrm{~S}_{2}-3.0 \times 2.0 \mathrm{~m}$ and $\mathrm{S}_{3}-2.0 \times 4.0 \mathrm{~m}$. The second factor comprised of plant density at three levels viz., $\mathrm{D}_{1^{-}}$- single plant per pit, $\mathrm{D}_{2}$ - double plants per pit and $\mathrm{D}_{3}$-triple plants per pit. However, third factor consisted of fertilizer dosages viz., $\mathrm{F}_{1}-100 \% \mathrm{RDF}, \mathrm{F}_{2^{-}}$ $125 \% \mathrm{RDF}$ and $\mathrm{F}_{3}-150 \%$ RDF along with their interaction effect viz., spacing and plant density (S x D), spacing and fertilizer ( $\mathrm{S} \times \mathrm{F}$ ), plant density fertilizer (D x F) as well as combined effect of spacing, density and fertilizers ( $\mathrm{S} \times \mathrm{D} \times \mathrm{F})$ consisting of total 09, 09, 09 and 27 treatments respectively. There were nine treatment combinations in each block; each treatment had a net area of 64 M2 having 16, 10 and 08 pits and allotted randomly.

The tissue culture planting has been taken up according to the experiment and irrigation was scheduled through drip irrigation as per water requirement of the crop. Fertilizer dose was calculated for banana at different growth stages according to treatment i.e. $100 \%, 125 \%$ and $150 \%$. It was calculated and applied in four split doses i.e., at 60,120, 180 and 240 days after planting in plant crop and in two splits doses i.e., half quantity at 90 days or 10-15 days after harvesting of first crop and rest after 60 days of first application in ratoon crop. The following biometrical observations was made at different stages of crop growth viz., $3^{\text {rd }}$ MAP, $5^{\text {th }}$ MAP, $7^{\text {th }}$ MAP and at shooting stage to find out feasibility of the spacing, plant density and nutrients. Absolute growth rate was expected for height and plant girth by using the following formula.

Absolute growth rate of plant height $\left(\mathrm{cm}^{-}\right.$day $^{-}$ $\left.{ }^{1}\right):\left\{\mathrm{H}_{2}-\mathrm{H}_{1} / \mathrm{t}_{2}-\mathrm{t}_{1}\right\}$

Absolute growth rate of plant girth $\left(\mathrm{cm} \mathrm{day}^{-1}\right)$ : $\left\{\mathrm{G} 2-\mathrm{G}_{1} / \mathrm{t}_{2}-\mathrm{t}_{1}\right\}$ Where, $\mathrm{H}_{1} \mathrm{G}_{1}$ and $\mathrm{H}_{2} \mathrm{G}_{2}$ are 
plant heights and girth at times $t_{1}$ and $t_{2}$ respectively. The number of suckers per pit was recorded at five months, six months, seven months, shooting and harvesting stage.

\section{Results and Discussion}

Pseudostem height, girth and number of leaves are important morphological parameter related to growth and development. Growth is a cellular process consisting of cell division, cell enlargement and cell differentiation. In the present study it can be observed that under different plant density and fertilizer levels, the vegetative growth in terms of pseudostem height and girth increased with age of the crop up to shooting. Further, rapid rate of increase in pseudostem height and girth was observed between $5^{\text {th }}$ MAP to shooting. Thereafter, the height and girth had slowed down.

The data on pseudostem height, girth number of leaves recorded 5 MAP and shooting stage as influenced by different levels of spacing, plant density per pit, fertilizers and their interaction on plant and ratoon crop of banana is given in Table 1 .

Significantly, the maximum pseudostem height of plant and ratoon crop was recorded in $\mathrm{S}_{1}(2.0 \times 2.0 \mathrm{~m})$ at shooting $(310.26$ and $304.47 \mathrm{~cm})$. But non significant differences exhibited at $5^{\text {th }}$ MAP. However, the minimum pseudostem height was registered in $\mathrm{S}_{3}$ in plant crop $(292.56 \mathrm{~cm})$ and ratoon crop $(288.44 \mathrm{~cm})$ at shooting.

The maximum pseudostem height in closer planting might be due to less spacing, low canopy led to higher interplant competition for light within a plot with the advancement of growth stages and more availability of nutrients compared to other treatments resulting tall and lanky growth as a result of pseudostem height was more. Similar to the present investigation Patel et al (2018) also reported that $2.0 \times 2.0 \mathrm{~m}$ spacing increased plant population per unit area, which provides less space for individual plant and in search of sunlight perhaps makes the plant upright resulting in tall growth. Similar results were also reported by Sindhupriya et al., (2018) in different banana cultivars.

With respect to plant density, the maximum pseudostem height was recorded in $\mathrm{D}_{3}$ (triple plants per pit) in plant and ratoon crop at $5^{\text {th }}$ MAP (153.48 and $154 \mathrm{~cm}$ ) and shooting (310.44 and $309.42 \mathrm{~cm}$ ) which was on par with $\mathrm{D}_{2}$ (double plant per pit) at the 5 MAP $(147.58$ and $147.42 \mathrm{~cm})$ and shooting (302.53 and $298.54 \mathrm{~cm})$. However, the minimum pseudostem height was registered in $D_{1}$ (single plant per pit) in $5^{\text {th }}$ and shooting in plant $(138.09$ and $292.00 \mathrm{~cm})$ ratoon crop (137.72and $283.73 \mathrm{~cm})$.

In plant and ratoon crops, the maximum height due to more plant population per unit area led to natural shading of plants resulting competition for space and light might have made the plants tall and lanky growth as a result of which the pseudostem height was maximum. Similarly in the prsent study line with Murugan, 2003 in Ney Poovan found that with increasing planting density triple plants per pit with clolser spacing pseudostem is increased invariably. Behera et al., (2016) reported triple plants per pit the competition for space and light might have made the plants tall and lanky as a result of which the plant height recorded was more and girth was the least under the spacing accommodating highest number of plants/ha.

There was a progressive increase in pseudostem height from $5^{\text {th }}$ MAP onwards with increase in planting density. Thereafter, the pseudostem height had slowed down at shooting. This could be due to increased plant population per unit area, which provides less 
space for individual plant and in search of sunlight perhaps makes the plant upright. Similar results were also recorded by Grand Naine (Gaonkar, 2019) and Quintal Nendran (Sindhupriya et al., 2018).

The pseudostem girth significantly maximum in plant and ratoon crop was recorded in $\mathrm{S}_{3}$ $(4.0 \times 2.0 \mathrm{~m})$ at $5^{\text {th }}$ MAP $(30.78$ and 27.41 $\mathrm{cm})$ and shooting $(61.91$ and $59.50 \mathrm{~cm})$ and it was on par with $\mathrm{S}_{2}(3.0 \times 2.0 \mathrm{~m})$ at $5^{\text {th }} \mathrm{MAP}$ (30.69 and $26.88 \mathrm{~cm}$ ) and shooting (60.73 and $57.56 \mathrm{~cm})$. However, the minimum pseudostem girth was registered in $S_{1}(2.0 \mathrm{x}$ $2.0 \mathrm{~m})$ in both plant $(28.22$ and $59.19 \mathrm{~cm})$ and ratoon crop (25.63 and $56.48 \mathrm{~cm}$ ) at $5^{\text {th }}$ MAP and shooting respectively.

With respect to plant density, the maximum pseudostem girth of plant and ratoon crop was recorded in $\mathrm{D}_{1}$ (single plant per pit) at $5^{\text {th }}$ MAP (31.85 and $28.24 \mathrm{~cm}$ ) and shooting stage $(62.61$ and $60.18 \mathrm{~cm})$, it was on par with $\mathrm{D}_{2}$. However, the minimum pseudostem girth was registered in $\mathrm{D}_{3}$ (triple plant per pit) in plant $(28.00$ and $58.60 \mathrm{~cm})$ and ratoon crop $(25.30$ and $54.81 \mathrm{~cm})$.

The highest pseudostem girth was recorded in wider spacing might be due to good canopy architexure which was benefited for maximum photosynthetic assimilation, considerably redused the height which led to increased in girth. Further, lower density led to less competition for soil moisture with more nutrients and sunshine led to better metabolic activities of cell. Increased pseudostem height and reduced pseudostem girth at higher density was reported by Chaudhuri and Baruah (2010) in Jahaji. Pseudostem girth increased at low plant density indicating that pseudostem girth and height of banana are inversely proportional to each other. Similar results were also noticed in Grand Naine, (Naik, 2016; Gaonkar, 2019).
In both plant and ratoon crop, the highest pseudostem girth was recorded in single plant and double plants per pit with wider spacing might be due to less plant population per unit area, better nutrient uptake and correct water balancing helped in getting good girth. Similarly, the present findings are line with (Gaonkar, 2019) and Quintal Nendran (Sindhupriya et al., 2018).

In the present study, it can be noted that under different spacings and plant density levels, the vegetative growth in terms of height and girth increased with age of the crop up to shooting. Further, rapid rate of increase in girth was recorded between $7^{\text {th }}$ to shooting. Thereafter, the pseudostem girth had slowed down from shooting. The good girth in lower density might be due to less competition for soil moisture, nutrient and sunshine. The pseudostem height and girth did not differ significantly with the different levels of fertilizers and interaction effects.

The number of leaves influenced significantly by different levels of spacing. The highest number of leaves per plant crop was registered in $\mathrm{S}_{3}$ at $5^{\text {th }}$ MAP (11.52) and at shooting (18.16), which was significantly higher over $S_{2}$ and $S_{1}$. Similar trend recorded in ratoon crop also. The lowest number of leaves was registered in $S_{1}(2.0 \times 2.0 \mathrm{~m})$ in plant and ratoon crop at $5^{\text {th }}$ MAP (10.61 and 9.70) and at shooting (16.47 and 15.54).

The highest number of leaves was registred in wider spacing might be due to sufficient space, more light interception and good congenial weather conditions. Hence, it indicates that sufficient reserve assimilation is a pre-requisite for higher leaf production in wider plants. Similar results were also noticed in Ney Poovan (Panjavarnam et al., 2018), Martaman (Naidu et al., 2015), Bantala (Behera et al., 2016), and Quintal Nendran (Sindhupriya et al., 2018). 
Number of leaves differed significantly among the density levels highest number of leaves of plant and ratoon crop registred in $\mathrm{D}_{1}$ (single plant per pit) at $5^{\text {th }}$ MAP (11.88 and 11.04) and at shooting (18.39 and 17.32), which was, significantly superior over $\mathrm{D}_{2}$ and $\mathrm{D}_{3}$. However, the lowest number of leaves was registered in $\mathrm{D}_{3}$ (triple plants per pit) in plant (10.50 and 16.26) and ratoon crop (9.31 and 15.54).

Both in plant and ratoon crop, the highest number of leaves was registered in single plant per pit with optimum spacing might be due to conginieal weather condition, higher amount of nutrients, correct availability of water results more number of leaves. In the present study, leaf emergence reduced under high density planting owing to lower temperature inside the canopy since temperature had played an important role and influenced on leaf emergence. Number of leaves showed decreasing trend with increasing plant population. Murugan (2003) reported number of leaves in high density planting were lower than the number of leaves in normal planting density. These findings are in conformity with banana cv. Grand Naine, Gogoi et al., (2015) Patel et al (2018) in banana cv. Grand Naine.

The significantly, the maximum number of leaves in plant and ratoon crop registered in $\mathrm{F}_{3}(150 \% \mathrm{RDF})$ at $5^{\text {th }}$ MAP (11.53 and 10.57). However, the minimum number of leaves was registered in $\mathrm{F}_{1}(100 \% \mathrm{RDF})$ in both plant and ratoon crop (16.53 and 14.37). At shooting stage, non significant results were recorded.

In both plant and ratoon crop, the highest number of leaves was registred in plants provided with $150 \%$ recommended dose of fertilizers and it was on par with $125 \%$ RDF might be due to higher amount of nutrient application resulted in more number of leaves.
The different workers on banana have reported that higher levels of nitrogen, phosphorus and potash promote production of more leaves. These findings are in conformity with banana cv. Ney Poovan (Panjavarnam et al., 2018), Grand Naine (Naik, 2016; Patel et $a l ., 2018$ ) and Quintal Nendran (Sindhupriya et al., 2018) in different banana varieties.

The data on the absolute growth rate (AGR) for pseudostem height, girth and sucker production as influenced by different levels of spacing, density fertilizers and their interaction effect of plant and ratoon crop are depicted in Table 2.

The absolute growth rate for pseudostem height exhibited a steady increase with the advancement of age and was peak during $7^{\text {th }}$ to $9^{\text {th }}$ MAP. The AGR of pseudostem height in plant density was different significantly at $3^{\text {rd }}$ MAP to $5^{\text {th }}$ in plant crop was recorded maximum in $\mathrm{D}_{2}(1.04 \mathrm{~cm}$ day- 1$)$, which was on par with $\mathrm{D}_{3}(1.03 \mathrm{~cm}$ day-1). But in ratoon crop, it was highest in $\mathrm{D}_{3}(1.12 \mathrm{~cm}$ day-1), which was on par with $\mathrm{D}_{2}(1.01 \mathrm{~cm}$ day-1). However, the minimum in $\mathrm{D}_{1}(0.90 \mathrm{~cm}$ day- 1$)$ and ratoon $(0.87 \mathrm{~cm}$ day- 1$)$. Remaining all the stages of banana crop growth was differed non-significantly. The absolute growth rate for pseudostem height was highest in closer planting $\mathrm{S}_{1}(2.0 \times 2.0 \mathrm{~m})$, it was highest in plant density with $\mathrm{D}_{3}$ and $\mathrm{F}_{3}$ compared to other levels. Compacted light intensity at ground level with increase in size of the plant canopy and age and solar energy conversion efficiency was maximum in closer spacing and minimum in wider spacing. The results of the present investigation also point out that there was a variation in growth rate in terms of pseudostem height with the age recording more growth rate during initial stages and less during later stages. These results are in corroborated with Martaman (Sailaja, 2014), Grand Naine, (Naik et al., (2016). 
Table.1 Pseudostem height, girth $(\mathrm{cm})$ and number of leaves per pit at different growth stages as influenced by spacing, density and fertilizer in tissue culture banana $c v$. Ney Poovan

\begin{tabular}{|c|c|c|c|c|c|c|c|c|c|c|c|c|}
\hline \multirow[t]{3}{*}{ Treatment } & \multicolumn{4}{|c|}{ Pseudostem height (cm) } & \multicolumn{4}{|c|}{ Pseudostem girth $(\mathrm{cm})$} & \multicolumn{4}{|c|}{ Number of leaves per plant } \\
\hline & \multicolumn{2}{|c|}{$5^{\text {th }}$ MAP } & \multicolumn{2}{|c|}{ Shooting } & \multicolumn{2}{|c|}{$5^{\text {th }}$ MAP } & \multicolumn{2}{|c|}{ Shooting } & \multicolumn{2}{|c|}{$5^{\text {th }}$ MAP } & \multicolumn{2}{|c|}{ Shooting } \\
\hline & $\begin{array}{l}\text { Plant } \\
\text { crop }\end{array}$ & $\begin{array}{c}\text { Ratoon } \\
\text { crop }\end{array}$ & $\begin{array}{l}\text { Plant } \\
\text { crop }\end{array}$ & $\begin{array}{c}\text { Ratoon } \\
\text { crop }\end{array}$ & $\begin{array}{l}\text { Plant } \\
\text { crop }\end{array}$ & $\begin{array}{c}\text { Ratoon } \\
\text { crop }\end{array}$ & $\begin{array}{c}\text { Plant } \\
\text { crop }\end{array}$ & $\begin{array}{l}\text { Ratoo } \\
\text { n crop }\end{array}$ & $\begin{array}{c}\text { Plant } \\
\text { crop }\end{array}$ & $\begin{array}{c}\text { Ratoon } \\
\text { crop }\end{array}$ & $\begin{array}{l}\text { Plant } \\
\text { crop }\end{array}$ & $\begin{array}{c}\text { Ratoon } \\
\text { crop }\end{array}$ \\
\hline Factor-01 & \multicolumn{10}{|c|}{ Factor-01-Spacing levels at 3 levels } & & \\
\hline $\mathbf{S}_{1}$ & 149.90 & 149.47 & 310.26 & 304.47 & 28.22 & 25.63 & 59.19 & 56.48 & 10.61 & 9.70 & 16.47 & 15.54 \\
\hline $\mathbf{S}_{2}$ & 146.81 & 145.55 & 302.15 & 298.77 & 30.69 & 26.88 & 60.74 & 57.56 & 11.43 & 10.58 & 17.29 & 16.30 \\
\hline $\mathbf{S}_{3}$ & 142.45 & 144.62 & 292.56 & 288.44 & 30.78 & 27.41 & 61.91 & 59.50 & 11.52 & 10.49 & 18.16 & 16.97 \\
\hline S.Em \pm & 2.99 & 3.75 & 4.70 & 4.89 & 0.69 & 0.49 & 0.57 & 0.46 & 0.17 & 0.14 & 0.30 & 0.30 \\
\hline C.D. at $5 \%$ & NS & NS & 13.65 & NS & 2.00 & 1.43 & 1.67 & 1.35 & 0.50 & 0.42 & 0.87 & 0.87 \\
\hline Factor-02 & \multicolumn{10}{|c|}{ Factor-02- Plant density at 3 levels } & & \\
\hline $\mathbf{D}_{1}$ & 138.09 & 137.72 & 292.00 & 283.73 & 31.85 & 28.24 & 62.61 & 60.18 & 11.88 & 11.04 & 18.39 & 17.32 \\
\hline $\mathbf{D}_{2}$ & 147.58 & 147.42 & 302.53 & 298.54 & 29.84 & 26.38 & 60.64 & 58.55 & 11.17 & 10.42 & 17.27 & 16.05 \\
\hline $\mathbf{D}_{3}$ & 153.48 & 154.51 & 310.44 & 309.42 & 28.00 & 25.30 & 58.60 & 54.81 & 10.50 & 9.31 & 16.26 & 15.44 \\
\hline S.Em \pm & 2.99 & 3.75 & 4.70 & 4.89 & 0.69 & 0.49 & 0.57 & 0.46 & 0.17 & 0.14 & 0.30 & 0.30 \\
\hline C.D. at $5 \%$ & 8.69 & 10.90 & 13.65 & 14.20 & 2.00 & 1.43 & 1.67 & 1.35 & 0.50 & 0.42 & 0.87 & 0.87 \\
\hline Factor-03 & \multicolumn{10}{|c|}{ Factor-03- Fertilizer at 3 levels } & & \\
\hline $\mathbf{F}_{1}$ & 142.82 & 144.54 & 299.17 & 293.67 & 29.51 & 26.18 & 60.11 & 57.29 & 10.78 & 9.91 & 16.95 & 15.87 \\
\hline $\mathbf{F}_{2}$ & 146.45 & 146.88 & 301.61 & 296.91 & 29.91 & 26.64 & 60.46 & 57.71 & 11.23 & 10.28 & 17.32 & 16.29 \\
\hline $\mathbf{F}_{3}$ & 149.89 & 148.22 & 304.20 & 301.11 & 30.27 & 27.10 & 61.28 & 58.54 & 11.54 & 10.57 & 17.66 & 16.66 \\
\hline S.Em \pm & 2.99 & 3.75 & 4.70 & 4.89 & 0.69 & 0.49 & 0.57 & 0.46 & 0.17 & 0.14 & 0.30 & 0.30 \\
\hline C.D. at $5 \%$ & $\mathrm{NS}$ & $\mathrm{NS}$ & NS & NS & NS & NS & NS & NS & 0.50 & 0.42 & NS & NS \\
\hline
\end{tabular}


Table.2 Absolute growth rate, suckers production per pit and days to emergence of suckers at different stages of crop growth as Influenced7 by different levels of spacing, plant density and fertilizer in tissue culture banana $c v$. Ney Poovan

\begin{tabular}{|c|c|c|c|c|c|c|c|c|c|c|c|c|}
\hline \multirow[t]{3}{*}{ Treatment } & \multicolumn{4}{|c|}{$\begin{array}{l}\text { Absolute growth rate }\left(\mathrm{cm} \mathrm{day}^{-1}\right) \text { for } \\
\text { pseudostem height }\end{array}$} & \multicolumn{4}{|c|}{$\begin{array}{l}\text { Absolute growth rate }\left(\mathrm{cm} \mathrm{day}^{-1}\right) \text { for } \\
\text { pseudostem girth }\end{array}$} & \multicolumn{4}{|c|}{ Suckers production per pit } \\
\hline & \multicolumn{2}{|c|}{$3^{\text {th }}-5^{\text {th }}$ MAP } & \multicolumn{2}{|c|}{$7^{\text {th }}-9^{\text {th }}$ MAP } & \multicolumn{2}{|c|}{$3^{\text {th }}-5^{\text {th }}$ MAP } & \multicolumn{2}{|c|}{$7^{\text {th }}-9^{\text {th }}$ MAP } & \multicolumn{2}{|c|}{$7^{\text {th }}$ MAP } & \multicolumn{2}{|c|}{ At shooting } \\
\hline & $\begin{array}{l}\text { Plant } \\
\text { crop }\end{array}$ & $\begin{array}{c}\text { Ratoon } \\
\text { crop }\end{array}$ & $\begin{array}{c}\text { Plant } \\
\text { crop }\end{array}$ & $\begin{array}{c}\text { Ratoon } \\
\text { crop }\end{array}$ & $\begin{array}{l}\text { Plant } \\
\text { crop }\end{array}$ & $\begin{array}{c}\text { Ratoon } \\
\text { crop }\end{array}$ & $\begin{array}{l}\text { Plant } \\
\text { crop }\end{array}$ & $\begin{array}{c}\text { Ratoon } \\
\text { crop }\end{array}$ & $\begin{array}{c}\text { Plant } \\
\text { crop }\end{array}$ & $\begin{array}{c}\text { Ratoon } \\
\text { crop }\end{array}$ & $\begin{array}{c}\text { Plant } \\
\text { crop }\end{array}$ & $\begin{array}{c}\text { Ratoon } \\
\text { crop }\end{array}$ \\
\hline Factor-01 & \multicolumn{10}{|c|}{ Factor-01- Spacing levels at 3 levels } & & \\
\hline $\mathbf{S}_{1}$ & 0.98 & 1.06 & 1.51 & 1.42 & 0.18 & 0.16 & 0.14 & 0.17 & 5.53 & 5.74 & 6.63 & 6.63 \\
\hline $\mathbf{S}_{\mathbf{2}}$ & 1.02 & 1.01 & 1.46 & 1.36 & 0.17 & 0.14 & 0.14 & 0.14 & 6.18 & 6.50 & 7.81 & 7.59 \\
\hline $\mathbf{S}_{\mathbf{3}}$ & 0.97 & 0.95 & 1.42 & 1.40 & 0.19 & 0.14 & 0.13 & 0.16 & 6.52 & 7.24 & 9.04 & 8.32 \\
\hline S.Em \pm & 0.05 & 0.06 & 0.08 & 0.09 & 0.01 & 0.01 & 0.01 & 0.01 & 0.23 & 0.11 & 0.10 & 0.12 \\
\hline C.D. at $5 \%$ & NS & NS & NS & NS & NS & NS & NS & NS & 0.64 & 0.33 & 0.29 & 0.34 \\
\hline Factor-02 & \multicolumn{10}{|c|}{ Factor-02- Plant density at 3 levels } & & \\
\hline $\mathbf{D}_{1}$ & 0.90 & 0.87 & 1.35 & 1.23 & 0.19 & 0.15 & 0.13 & 0.16 & 5.93 & 6.78 & 8.33 & 7.82 \\
\hline $\mathbf{D}_{2}$ & 1.04 & 1.01 & 1.46 & 1.44 & 0.19 & 0.15 & 0.14 & 0.16 & 6.60 & 6.67 & 8.04 & 7.84 \\
\hline $\mathbf{D}_{3}$ & 1.03 & 1.12 & 1.58 & 1.52 & 0.16 & 0.14 & 0.15 & 0.14 & 5.71 & 6.03 & 7.11 & 6.88 \\
\hline S.Em \pm & 0.05 & 0.06 & 0.08 & 0.09 & 0.01 & 0.01 & 0.01 & 0.01 & 0.23 & 0.11 & 0.11 & 0.12 \\
\hline C.D. at $5 \%$ & 0.16 & 0.19 & NS & NS & NS & NS & NS & NS & 0.64 & 0.33 & 0.29 & 0.34 \\
\hline Factor-03 & \multicolumn{10}{|c|}{ Factor-03- Fertilizer at 3 levels } & & \\
\hline $\mathbf{F}_{1}$ & 0.95 & 1.00 & 1.45 & 1.41 & 0.18 & 0.15 & 0.14 & 0.15 & 5.71 & 6.27 & 7.66 & 7.25 \\
\hline $\mathbf{F}_{2}$ & 1.00 & 1.01 & 1.47 & 1.40 & 0.18 & 0.15 & 0.14 & 0.15 & 5.96 & 6.44 & 7.78 & 7.59 \\
\hline $\mathbf{F}_{3}$ & 1.02 & 1.00 & 1.48 & 1.38 & 0.18 & 0.15 & 0.14 & 0.15 & 6.57 & 6.78 & 8.04 & 7.69 \\
\hline S.Em \pm & 0.05 & 0.06 & 0.08 & 0.09 & 0.01 & 0.01 & 0.01 & 0.01 & 0.23 & 0.11 & 0.10 & 0.12 \\
\hline C.D. at $5 \%$ & NS & NS & NS & NS & NS & NS & NS & NS & 0.64 & 0.33 & 0.29 & 0.34 \\
\hline \multicolumn{13}{|c|}{ Interaction effect (S X D) } \\
\hline $\mathbf{S}_{1} \mathbf{D}_{1}$ & 0.83 & 0.96 & 1.26 & 1.25 & 0.20 & 0.16 & 0.134 & 0.191 & 5.06 & 5.44 & 6.65 & 6.58 \\
\hline $\mathbf{S}_{1} \mathbf{D}_{2}$ & 0.99 & 1.04 & 1.50 & 1.40 & 0.19 & 0.7 & 0.154 & 0.172 & 5.94 & 6.09 & 6.87 & 6.92 \\
\hline $\mathbf{S}_{1} \mathbf{D}_{3}$ & 1.13 & 1.17 & 1.76 & 1.63 & 0.16 & 0.16 & 0.158 & 0.147 & 5.59 & 5.70 & 6.37 & 6.42 \\
\hline
\end{tabular}




\begin{tabular}{|c|c|c|c|c|c|c|c|c|c|c|c|c|}
\hline$S_{2} D_{1}$ & 0.92 & 0.91 & 1.43 & 1.12 & 0.19 & 0.16 & 0.146 & 0.145 & 6.25 & 6.78 & 8.27 & 8.03 \\
\hline $\mathbf{S}_{2} \mathbf{D}_{2}$ & 1.097 & 0.98 & 1.45 & 1.45 & 0.18 & 0.13 & 0.136 & 0.154 & 6.85 & 6.93 & 8.53 & 8.08 \\
\hline $\mathbf{S}_{2} \mathbf{D}_{3}$ & 1.06 & 1.14 & 1.51 & 1.51 & 0.15 & 0.14 & 0.140 & 0.126 & 5.45 & 5.81 & 6.63 & 6.65 \\
\hline $\mathbf{S}_{3} \mathbf{D}_{1}$ & 0.96 & 0.76 & 1.36 & 1.33 & 0.20 & 0.15 & 0.111 & 0.164 & 6.48 & 8.16 & 10.07 & 8.88 \\
\hline $\mathbf{S}_{3} \mathbf{D}_{\mathbf{2}}$ & 1.05 & 1.02 & 1.44 & 1.48 & 0.20 & 0.15 & 0.145 & 0.176 & 6.10 & 6.70 & 8.73 & 8.52 \\
\hline $\mathbf{S}_{\mathbf{3}} \mathbf{D}_{\mathbf{3}}$ & 0.90 & 1.06 & 1.48 & 1.41 & 0.18 & 0.14 & 0.152 & 0.146 & 6.01 & 6.57 & 8.32 & 7.58 \\
\hline S.Em \pm & 0.10 & 0.11 & 0.15 & 0.16 & 0.023 & 0.018 & 0.032 & 0.025 & 0.38 & 0.20 & 0.17 & 0.21 \\
\hline C.D. at $5 \%$ & NS & NS & NS & NS & NS & NS & NS & NS & NS & 0.58 & 0.52 & 0.59 \\
\hline \multicolumn{13}{|c|}{ Interaction effect (S X F) } \\
\hline S.Em \pm & 0.10 & 0.11 & 0.15 & 0.16 & 0.023 & 0.018 & 0.032 & 0.025 & 0.38 & 0.20 & 0.17 & 0.21 \\
\hline C.D. at $5 \%$ & NS & NS & NS & NS & NS & NS & NS & NS & NS & NS & NS & NS \\
\hline \multicolumn{13}{|c|}{ Interaction effect (D X F) } \\
\hline S.Em \pm & 0.10 & 0.11 & 0.15 & 0.16 & 0.023 & 0.018 & 0.032 & 0.025 & 0.38 & 0.20 & 0.17 & 0.21 \\
\hline C.D. at $5 \%$ & NS & NS & NS & NS & NS & NS & NS & NS & NS & NS & NS & NS \\
\hline \multicolumn{13}{|c|}{ Interaction effect (S X D X F) } \\
\hline S.Em \pm & 0.17 & 0.19 & 0.26 & 0.27 & 0.040 & 0.030 & 0.055 & 0.025 & 0.67 & 0.35 & 0.31 & 0.35 \\
\hline C.D. at $5 \%$ & NS & NS & NS & NS & NS & NS & NS & NS & NS & NS & NS & NS \\
\hline
\end{tabular}

Foote note

\begin{tabular}{|c|c|c|c|}
\hline Spacing & $\mathbf{S}_{\mathbf{1}} \mathbf{- 2 . 0} \times \mathbf{2 . 0} \mathbf{~ m}$ & $\mathbf{S}_{\mathbf{2}} \mathbf{- 3 . 0} \times \mathbf{2 . 0} \mathbf{~ m}$ & $\mathbf{S}_{\mathbf{3}} \mathbf{- 4 . 0} \times \mathbf{2 . 0} \mathbf{~ m}$ \\
\hline Plant density & $\mathrm{D}_{1}-$ Single plant per pit & $\mathrm{D}_{2}-$ Double plants per pit & $\mathrm{D}_{3}-$ Triple plants per pit \\
\hline Fertilizer & $\begin{array}{c}\mathrm{F}_{1}-100 \% \text { RDF }(200-100-300 \mathrm{~g} \text { NPK } \\
\text { per pit) } 100100-\end{array}$ & $\begin{array}{c}\mathrm{F}_{2}-100 \% \text { RDF }(250-125-375 \mathrm{~g} \text { NPK } \\
\text { per pit) }\end{array}$ & $\begin{array}{c}\mathrm{F}_{1}-100 \% \mathrm{RDF}(300-150-450 \mathrm{~g} \text { NPK } \\
\text { per pit }\end{array}$ \\
\hline & NS-Non Significant & RDF-Recommended Dose of & MAP- Months After Planting \\
\hline
\end{tabular}


The absolute growth rate for pseudostem girth exhibited a steady decrease with the advancement of age and was peak during earlier and middle stage of growth. Later decreased growth rate was noticed. Nonsignificant differences were obtained for with respect spacing, density fertilizers and their interaction effect of plant and ratoon crop during $3^{\text {rd }}-5^{\text {th }}$ and $7^{\text {th }}-9^{\text {th }}$ period.

It was highest in medium planting $S_{2} D_{1}$ and $\mathrm{F}_{3}$ compared to other levels might be due to reduced pseudostem height, which led to more increase in stem girth due to more availability of nutrients compared to other treatments. The decrease in girth in closer spacing was due to increase in pseudostem height of the plant as a resulted in diversion of assimilates to increase in height at the expense of girth. Sindhupriya et al., (2018) reported that, optimum AGR for pseudostem height and girth was recorded in wider spacing $(2.4 \mathrm{~m} \mathrm{x} 2.1 \mathrm{~m})$ compared to closer spacing. The minimum AGR for height and stem girth in wider spacing might be due to less competition for soil moisture, nutrient and sunshine.

The maximum AGR for pseudostem height and girth was recorded in (125 per cent RDF). The results of the present study pointed out that there was a variation in growth rate in terms of plant height with the age registering more growth rate during initial stages and less during later stages. The present results are in accordance with Jahaji (Gogoi, 2015) and Grand Naine, (Naik, 2016)

The significantly maximum number of suckers production per pit of plant and ratoon crop was obtained in $\mathrm{S}_{3}(4.0 \times 2.0 \mathrm{~m})$ at $7^{\text {th }}$ MAP (6.52 and 7.24) and shooting (9.04 and 8.32 ), which was found to be on par with $\mathrm{S}_{2}$ $(3.0 \times 2.0 \mathrm{~m})$ at 7 MAP (6.12). However, the lowest number of suckers was registered in $\mathrm{S}_{1}$ in plant 5.53 and 6.63 and ratoon crop (5.74 and 6.63).
In plant and ratoon crop, the highest number of suckers produced per pit in wider spacing could be due to availability of plenty of space between plants, good light intervention, nutrient and soil moisture uptake led to more suckers production and also due to genetic makeup (diploids are vigorous in growth behavior). Similar results were also reported by Naik (2016) in Grand naine.

With respect to plant density significantly highest suckers production per pit of plant and ratoon was registered in $\mathrm{D}_{1}$ at shooting (8.33 and 7.84) and it was on par with $\mathrm{D}_{2}(8.04$ and 7.84). During $7^{\text {th }}$ MAP significantly registered in $\mathrm{D}_{2}(6.60)$ and it was on par with $\mathrm{D}_{1}(5.93)$. In ratoon crop also highest was registered in $\mathrm{D}_{1}$ at $7^{\text {th }}$ MAP (6.78) and it was on par with $\mathrm{D}_{2}$ (6.67). The lowest number of suckers production per pit in $\mathrm{D}_{3}$ in plant (5.71 and 7.11) and ratoon crop (6.03 and 6.88).

In the present investigation, both plant and ratoon crop, the highest number of suckers produced per pit in low and medium density (single and double plants per pit) with wider spacing could be due to good light involvement, soil moisture uptake and good farming unit leads to more suckers production and also genetic ploidy level i.e., diploids are vigorous in growth behavior. Gaonkar (2019) reported the sucker production was minimal at high density levels compared to normal density at all the stages of growth. The results of the present study are in accordance with the findings of Patel et al., (2018) in banana cv. Grand Naine, and Sindhupriya et al., (2018) in banana cv. Quintal Nendran.

The different levels of fertilizer significantly influenced on number of suckers production per pit in plant and ratoon crop. The maximum number of suckers (6.57 and 8.04) was found in $\mathrm{F}_{3}(150 \% \mathrm{RDF})$ and it was on par with $F_{2}$ (125\% RDF) (5.96 and 7.78). In ratoon crop also significantly, the maximum number suckers production per pit 6.78 and 
7.69 was recorded in $\mathrm{F}_{3}$ and it was on par with $\mathrm{F}_{2}$ (6.44 and 7.59). The minimum number of suckers was recorded in $\mathrm{F}_{1}(100 \% \mathrm{RDF})$ in both main and ratoon crop from $7^{\text {th }}$ MAP (5.71 and 6.27) to shooting (7.66 and 7.25).

In plant and ratoon crop, the highest suckers production per pit was registered in plants supplied with $150 \%$ recommended dose of fertilizers and it was on par with $125 \%$ RDF might be due to higher amount of nutrient supply and ample moisture led to more number of suckers. The different workers on banana have reported NPK levels promote production of more suckers. These findings are in conformity with Sindhupriya et al., (2018) in banana cv. Quintal Nendran. In present research, the maximum number of suckers was found in wider spacing, low plant density and high fertilizer dose. So sucker production was minimal at high density levels compared to normal density of growth.

The interaction effects between spacing and density levels on suckers per pit was found significant in plant and ratoon crop. The treatments $\mathrm{S}_{3} \mathrm{D}_{1}(4.0 \times 2.0 \mathrm{~m}$ with single plant per pit) and $\mathrm{S}_{2} \mathrm{D}_{1}$ recorded maximum suckers per pit at shooting (10.07 and 8.88) (8.53 and 8.08). It was on par with $\mathrm{S}_{3} \mathrm{D}_{2}(4.0 \times 2.0 \mathrm{~m}$ with 2 plants per pit)(8.73 and 8.52). The minimum number of suckers was recorded in $\mathrm{S}_{1} \mathrm{D}_{1}(2.0 \times 2.0 \mathrm{~m}$ with single plant per pit $)$ at shotting (6.65 and 6.58).

In main and ratoon crop, the highest suckers production per pit significantly registered in $\left(\mathrm{S}_{3} \mathrm{D}_{1}\right)$ and $\left(\mathrm{S}_{2} \mathrm{D}_{1}\right)$ wider spacing with single plant per pit and medium spacing with single plant per pit may be due to more spacing between plants, ample light intensity, better moisture with nutrient uptake led to more suckers. Gaonkar (2019) reported that, the maximum number of suckers was found in lower plant density with maximum level of fertilizer dose. At shooting stage, the interaction effect of $\mathrm{S}_{2} \mathrm{P}_{1}(2.5 \times 2.0 \mathrm{~m}$ with 2 plants per hill) recorded maximum (15.52) suckers per hill, followed by $\mathrm{S}_{3} \mathrm{P}_{2}(2.5 \times 2.5 \mathrm{~m}$ with 3 plants per hill). These findings are in accordance with Sindhupriya et al., (2018) in Quintal Nendran.

The interaction effect of different levels of spacing and fertilizers ( $\mathrm{S} \times \mathrm{F}$ ), density and fertilizers (D x F) as well as combined effect of spacing, density and fertilizers ( $\mathrm{S} \times \mathrm{D} \times \mathrm{F}$ ) showed non-significant.

\section{References}

Anonymous, 2017, Indian Horticultural Database, National Horticulture Board, Govt. of India. Anonymous, 2018, India Export Data. Mumbai, pp. 22

Behera, S., Das, A. K., Mishra, N. and Mishra, P. P., 2016, Effect of Spacing on Growth and yield of banana $c v$. Grand Naine and Bantala. Intl $J$. Tropical Agri., 34 (1): 39-43.

Chaudhari, P. and Baruah, K., 2010, Studies on planting density in banana $c v$. Jahaji (AAA). Indian J. Hill Farming, 23(2): 31-38.

Gogoi, B., Khangia, B., Brauh, K. and Khousal, A., 2015, Effect of high density planting and nutrient on growth and yield of Banana $c v$. Jahaji (Musa AAA). Intl. J. Agril. Inno. \& Res., 315: 1465-1469.

Gaonkar, Y. A., 2019, Studies on plant density and nutrient requirement in banana $c v$. Grand Naine. Ph. D.(Hort.) thesis submitted to Vasantrao Naik Marathwada Krishi Vidyapeeth Parbhani. India

Husameldin, H. M. and Fatima, Y. G. 2013, Effect of different levels of planting distances, irrigation and fertigation on growth characters of main and ratoon banana crop cv. Grand Naine. Global J. Pl. Ecophysiology, 3 (2):104-109. 
Kumar, N. and Nalina, L., 2002, Research on high density planting of banana in Tamil Nadu- Resume. South India Hort. 49 (Special): 1-5.

Murugan, V., 2003, Influence of fertigation on growth and productivity of banana cv. Ney Poovan under different planting densities. M.Sc. Thesis. Tamil Nadu Agricultural University, Coimbatore.

Naidu, M. M., Mamata, K., Lakshmi, N. R and Rajashekaram, T., 2015, Effect of plant density and fertigation on growth and productivity of banana $c v$. Martaman (AAB). J. Agril. Engineering \& Food Tech., 2 (3): 178180.

Naik, M. H. 2016. Studies on high density planting, fertigation and postharvest chemical treatments in banana (Musa acuminatal.) $c v$. Grand Naine. Ph.D (Fruit Science) Thesis, submitted to Dr. Y.S.R. Horticultural University, Rajendranagar.

Naik M. H., K. Vanjalatha, T. Ramesh and P. Prasanth, 2016, Influence of high density planting and fertigation on physiological parameters, flowering and yield of banana (M. accuminata L.) cv. Grand Naine of main and ratoon crop. Inter. J. Res. in Sci. Engn. and Tech. 3 (10): 2800-2808.

Panjavarnam, G., Parthiban, A., Subbiah. P. AND Jeyakuma, N., 2018, effect of planting density and nutrient management on yield, fruit quality and post harvest characters in banana $\mathrm{cv}$. Ney Poovan under coconut. Int.J.Curr.Microbiol.App.Sci., (2018) 7 (2): 515-525.

Patel, M. J., Sitapara, H. H., Shah, N. I. and Pat, H. R., 2018, Effect of different levels of planting distance and fertilizers on growth, yield and quality of banana cv. Grand Naine. $J$. Pharmacognosy and Phytochemi., 7(2): 649-653.

Sailaja, K., 2013, effect of plant density and fertigation on growth and productivity of banana cv. Martaman (AAB), M.Sc. (Hort.) Thesis submitted to Dr. Y.S.R Horticultural University, India.

Sindhupriya, V., Auxcilia, J. and Soorianathasundaram, K., 2018, Effect of planting density and nutrient requirement on growth and development of banana cv. Quintal Nendran (AAB). Int. J. Curr. Microbiol. App. Sci., 7(11): 3060-3068.

\section{How to cite this article:}

Yallesh Kumar, H. S., Kulapati Hippargi, B. S. Shivakumar, I. B. Biradar, M. P. Basavarajappa and Mallikarjuna G. Awati. 2020. Effect of Planting Density and Fertilizers on Growth and Development of Tissue Culture Banana $c v$. Ney Poovan (AB) under Hill Zone of Karnataka. Int.J.Curr.Microbiol.App.Sci. 9(08): 3846-3856. doi: https://doi.org/10.20546/ijcmas.2020.908.443 